JOLANTA MIGDAŁ

Uniwersytet im. Adama Mickiewicza w Poznaniu

\title{
VARIATION AND NORMALIZATION OF THE POLISH LANGUAGE IN THE OLD PRINTS FROM THE FIRST HALF OF THE 16TH CENTURY
}

In modern times, a standard has been defined as the set of linguistic units - accepted by a given society - and the rules which determine the ways and the extent of possible combinations of such units (Kurkowska 1986: 18; EJO 1993: 362). Such a standard is discernible in texts which are based on the social custom to use specific linguistic units i.e., language usage. This is a practical standard which becomes visible in texts. According to Halina Kurkowska, there is another definition of a standard having even a longer tradition. According to it, the standard determines rules governing the use of a particular language means or a set of such means imposed by usage, but, at the same time, also formulated by linguists studying and codifying language. Such rules should be followed under the threat of punishment (Kurkowska 1986: 19-20). Most probably, this interpretation of a standard led to the introduction by Witold Taszycki and Tadeusz Milewski of the term language model, which "is not a generally recognized standard and being in opposition to it is not a mistake. Such a model is rather a specific style or a stylistic mode which affects those who write and speak, originally driven by language snobbism. [...] A model may be imitated or not, whereas one must follow the standard under the threat of being misunderstood and ridiculed" (Taszycki, Milewski 1956: 64, 65). On the basis of this terminological proposal, Władysława Książek-Bryłowa provides the following definition for the language standard of the 16th century: "a standard can be a set of uniform grammatical and lexical means, most common in a particular circle of speakers, preserved by tradition, which can also serve as the language model for language users outside this circle" (Książek-Bryłowa 1986: 139). If we completely adopted the definition of the standard which provides sanctions for not pursuing it, we would not be able to talk about it before the 16th century. As late as the second half of the 16th century, beginning with the grammar by Statorius-Stojeński from 1568, there began to appear sources precisely determining a theoretical standard (comp. Rzepka 1985: 19).

A standard is an undisputable and indispensable condition for the existence of a literary language. The manifestations of its influence are visible in the earliest written monuments of Polish. Stanisław Urbańczyk notices directly that "since we started writing in Polish, supradialectical standards were observed in historical written texts" (Urbańczyk 1979: 
194). Other authors also wrote about the existence of a standard in the Old-Polish period, among others Stanisław Rospond (Rospond 174-175) and Bogdan Walczak (Walczak 1993: 34-36). Thus, normalization accompanies the Polish literary language from its very origins and consists in "removing superfluous diversity, instability, ambiguity in the language and the introduction of a uniform standard" (Bajerowa 1983: 19)1. This diversity, instability and ambiguity is related to the occurrence - at different stages of development of the language - of similar units, partly identical, competing with one another, "which are either alterations different in form and fulfilling the same function, or they have the same (similar) form and differ in function" (Bajerowa 1983: 19). Such elements are linguistic variants, whereas the principle of normalization is to reduce variation.

There are many different reasons determining the functioning of linguistic variants. Generally, they can be divided into two groups. The first group includes intralinguistic factors, the second group extralinguistic (social ${ }^{2}$ ) factors. According to Władysława Książek-Bryłowa the following determinants can be indicated with reference to the 16th century:

- "religious reformatory movement;

- the interest of the nobility in public life connected with their insurgency against the secular as well as ecclesiastical magnates, and, consequently:

- creation of numerous political writings in Polish,

- more vivid debate at regional councils and in parliament (Pol. Sejm) where there was strife for the Polish language,

- increased role of the townspeople and the beginning of literary activity of writers of plebeian origin, for example, Biernat of Lublin, Balthasar Opec, Jan of Koszyczki, Andrzej Glaber of Kobylin [...],

- development of the educational system,

- development of printing" (Książek-Bryłowa 1986: 139-143).

These external conditions were accompanied by the regional influences brought by the users of the Polish language, the quality of their linguistic awareness and the stylistic traditions of various writing genres. Nevertheless, all of the above do not form a complete list of factors influencing the development of and changes in variation. It must be underlined that among the most important sources of variation in the 16th century there were forms and structures reflecting different types of development as well as co-existence of various dialectal forms. Also the influences of foreign languages contribute to the expansion of variation ${ }^{3}$.

${ }^{1}$ Here I would like to notice that Irena Bajerowa uses the term wariancja instead of wariantywność (variation). In contrast, I consequently use the second term following the opinion of Teresa Skubalanka who considers the term more suitable because of euphonic reasons.

2 With reference to inflection, it was discussed in detail by Władysława Książek-Bryłowa, who pointed to the following linguistic factors: morphological, paradigmatic and quantitatively-semantic. Comp. Książek-Bryłowa 1994: 151-167; comp. also Książek-Bryłowa 1987: 191-197.

${ }^{3}$ According to Tadeusz Lewaszkiewicz, these foreign influences, and especially the contacts with the languages of superior culture, i.e., high-prestige languages, "were the main causative factor of increased linguistic competence in the early period of formation of the literary languages of the European cultural circle". However, constant improvement of the general functional-linguistic competence formed the basic current which, accompanied by normalization, influenced the historical-linguistic process of creation of the Polish literary language. 
Such a great number of various factors, which, on the one hand, contribute to the creation of variant forms, and, on the other hand, influence their elimination from language (in other words, the normalization process), leads to the distinction of many different types of variants. They enter into varied configurations of reciprocal oppositions. Chronologically, there occur obsolete variants, old and new ones, innovative as well as living and dead and relict ones; with regard to origin - the vernacular ones, familiar and foreign, loaned ones; with regard to their scope - nationwide, general and dialectal as well as regional A and regional B; with regard to function - expressive, distinct and neutral, literary and colloquial (Urbańczyk 1977: 77; Skubalanka 1992: 20-21; Książek-Bryłowa 1996: 21).

Linguistic variation can be examined at the synchronic level, this is the so-called static variation. In the opinion of Irena Bajerowa, this kind of research explores the characteristics of variants whose task is to differentiate (to separate and integrate systemic linguistic units in text). But there is also dynamic variation that manifests a tendency to eliminate or limit the variety of forms, thus playing an important role in the evolution of a language. This type of variation "provokes normalization, and normalization determines the basic direction of development of a general language. As both types of the discussed variation affect the same linguistic elements, we can observe the relationships between them. These relationships follow the principle stating that "every dynamic variation is originally static" but not every static variation transforms into a dynamic one because not always the variants are eliminated" (Bajerowa 1983: 22-23).

In diachronic studies, among the variants occurring in the language, we can distinguish several types whose character is connected with the type of changes they undergo. This kind of classification was presented by Władysława Książek-Bryłowa (Książek-Bryłowa 1992: 171-177; Książek-Bryłowa 1994: 141-150)4. Consequently, we can identify inert variants, that is the forms and structures which have been preserved in the Polish language without alteration. They reflect the forms created already in the Proto-Slavic language. Often, they have no other variant forms. They are opposed by innovative variants which include new forms created at different stages of development of Polish. They may have a long-lasting character. Such variants, although with different frequency, have been preserved in the language until today. On the other hand, in the history of the Polish language we must also distinguish periodical variants, characteristic only for some stages in the history of the language. As far as these forms are concerned, we can trace the entire period of their functioning in Polish, determine the time of their creation and disappearance.

Due to the direction of changes the innovative variants were subjected to in their development, they can be divided into two groups: the progressive and regressive variants. The number of progressive variants is constantly growing. Such forms enter into the language and become established in it. At the initial stage, when their share in a given category reaches up to $5 \%$, they are called the ascending or entering variants. As their frequency increases and their share is from $5 \%$ to $40 \%$, they become the developmental variants. At

According to Tadeusz Lewaszkiewicz, the contacts with Latin and Czech languages "were the most important source of linguistic competence of Polish almost until the mid-16th century", comp. Lewaszkiewicz 1994.

${ }^{4}$ The types distinguished by Władysława Książek-Bryłowa referred to inflectional variants, but in my opinion this classification can be referred to variant forms from other language areas. 
the next stage, when the competing forms reach the numbers close to their average maximum and they proliferation is equal between $40 \%$ and $60 \%$, they must be considered as the equivalent variants. Consecutively, if one of the forms exceeds the threshold of $60 \%$, it must be called a dominating variant. In contrast, if the share of a given form falls below $40 \%$ and gets as low as 5\%, it becomes a disappearing variant. Below 5\% we speak of relict variants that finally disappeared from language and can be observed from historical perspective. Generally, the disappearing and relict variants belong to the group of regressive variants. Typically, they are leas and less frequent and finally disappear from the language.

It must be recapitulated here that the process of normalization is based on limitation of language variation. Its elimination primarily consists in deleting variants that are "inferior" in some respects. The "superior", winning variant is usually a form or structure which belongs to a more numerous category or to a more stable category, independent, primary, although sometimes other factors may decide about the proliferation of one of the variants, for instance, of phonetic nature. The second means of the elimination of superfluous variation is by assigning one of the variants a new, distinct, special function by which it actually ceases to be a variant (Bajerowa 1983: 20-22). Following Irena Bajerowa (Bajerowa 1980b: 111; Bajerowa 1984: 77) and Wojciech Ryszard Rzepka (Rzepka 1985: 18-19) we can talk about normalization of the language when one of the variants exceeds $75 \%$ of uses. However, complete normalization is observed only when the threshold of $95 \%$ has been passed. The stage preceding it (above $75 \%$ but less than $95 \%$ ) must be reckoned as incomplete normalization. It should be assumed that the process of normalization begins after one of the variants exceeds its developmental average which is $50 \%$. Thus, the stage from $51 \%$ to $74 \%$ must be interpreted as preliminary normalization.

It is worth noticing here, following Irena Bajerowa that normalization may be interpreted more narrowly or widely. The interpretation depends on the extent of linguistic category which is regarded as a foundation of variation (Bajerowa 1980b: 105) 5 . Of course, we must remember that a wider or more narrow interpretation of the significance of normalization has no relationship with the evaluation of the scope of the discussed categories.

Using the details of percentage share of particular variants presented above, we can determine a practical standard. Complete normalization can be assumed when the practical standard is recognized by the theoretical one (Bajerowa 1980b: 105). Such a standard is determined by clues included in metalinguistic utterances in different types of grammar books, handbooks and dictionaries. This kind of approval for the practical standard, the standard observed in usage, in linguistic practice, defining the concept of the standard in the 16th century, is only possible after the first half of that century. This is because theory develops fully as late as the end of the 18th century, whereas for earlier periods there is lack of adequate sources of the theoretical standard (Bajerowa 1983: 20). As Irena Bajero-

\footnotetext{
${ }^{5}$ As an example, we can analyse nominal grammatical forms, treating a noun as one entity and taking into account all grammatical genders but we can also study variation of forms within just one gender. Because of such different scopes, the observations regarding normalization will definitely be different. Another example is the analysis of plural dative forms of all masculine nouns. In the 16th century, among such forms there occurred variant suffixes -om and -am. If we restrict the above category exclusively to masculine nouns, which do not inflect according to the feminine paradigm of the type stuga, it will turn out that variation and normalization connected with it are shaped differently.
} 
wa writes, the evolution of the Polish language before the 19th century comes about in a more simple way, in one direction, only at the level of usage. "Despite the lack of academic grammar books, of grammar books intended for Poles, normalization develops steadily in the course of many individual choices in language usage" (Bajerowa 1983: 20). As a consequence, only the study of the practical standard is viable for the first half of the 16th century. The absence of one general theoretical standard and also the fact that the standard becomes realized in usage, that is in concrete texts, contributes to the occurrence of particular standards in the language ${ }^{6}$. Such particular standards existed in the period of our interest and were connected with various linguistic customs established by individual publishing houses. Those customs were popularized in the writings which were published there (Książek-Bryłowa 1986: 141-143; Książek-Bryłowa 1992: 188; Książek-Bryłowa 1994: 165-166).

In the first half of the 16th century, the varied Polish language, full of different language variants, still in the process of creation posed a challenge for the contemporary printers. They faced the necessity to standardize and normalize Polish. Irena Bajerowa wrote: "they were forced to do so because of the market strife for customers, a competitive fight in which the winners were to become the publications written in careful language, better standardized and well-coordinated with the realm of thought" (Bajerowa 1980a: 12). With the rise of print not only the circle of readers grew wider but also the audience of Polish books changed. Not many readers of manuscript books were very well educated people, ready to overcome difficulty in understanding text. In contrast, the readers of printed books recruited not only from educated circles and, consequently, it was impossible to preserve such a wide scope of variation. It can be said that in this way the objective situation ${ }^{7}$ contributed to the intensification of the normalization processes of the Polish literary language. Sixteenth-century printers, mainly from Cracow, embarked upon this task. Among them, we must mention not only the technical workers of printing houses, but mainly the editors and proofreaders. Many historians of language consider printers, or more generally, the people involved in book publishing, as main normalizers of the literary Polish. Bogdan Walczak wrote that "literary language was created by mediaeval clergy - or more precisely its intellectual elite - owing to their writing activity," (Walczak 1993: 38). But he also pointed out that: "such a conclusion is not, on no account, in contradiction to the consolidated communis opinio of historians of language about the role of Cracow printers. Stieber was right when he stated that $>>[\ldots]$ unification of the Polish written language was finally completed in the 16 th century by printers, mainly from Cracow $<<$. Of course the term "finally" must be understood in a relative way. The printers completed the first stage of

\footnotetext{
${ }^{6}$ This term has been introduced by Marian Borecki who wrote: "a relative balance of language varieties, at least when considering some variant forms, is something abnormal in an individual act of speaking and writing. Thus, usually in individual texts, one of the varieties decidedly prevails over another or becomes exclusive and only the material compiled from a great number of different writings may exhibit the balance of these forms. In other words, to contend that in the language of a certain group there is a balance of different linguistic varieties most often means that some speak in one way whereas others in a different way, as if particular standards were created" (Borecki 1974: 8).

${ }^{7}$ Also comprising the economic considerations. In order for a book to generate profit for a printing house, it had to be popular so as not to discourage potential readers with its non-standard, even only in some aspects, language.
} 
formation and development of the Polish literary language. Those printers (and more exactly not printers as entrepreneurs but editors, proofreaders, typesetters etc.) undeniably played a great role in creation, preservation and popularization of the general Polish language standard" (Walczak 1993: 38).

In order to present the normalization process, the best way is to apply the method of synchronic cross-sections, i.e., the sections placed perpendicularly on the axis of time. This method was proposed and introduced into the history of language by Irena Bajerowa (Bajerowa 1969: 85-87; Bajerowa 1964). The method was based on the proposal of Charles Moraze resulting from the principles of structuralism. The history of language becomes divided into time structures, and within them the synchronic cross-sections are isolated. The opening and closing dates delimit the section of time which is characterized by the presence of a certain defined phenomenon. In this manner, it is possible to present and analyse the factors that determine: the appearance, existence, disappearing and disappearance of a particular linguistic phenomenon. The method of synchronic cross-sections is based on the study of a language at specific historical moments and on synchronic description of that condition. The process of normalization, its development contributing to the formation and refinement of literary language can be showed by comparison of the situation at specific time sections.

When observing how variation was limited and studying normalization in the 16th century (but also in other periods), we must bear in mind that various factors influence linguistic processes. They may influence normalization and may modify its progress. Wojciech Ryszard Rzepka mentions such factors characterizing the differences in the course of the processes demorphologization of gender in plural noun (Rzepka 1985: 21-24). In the first place, we must remember about the phenomenon of lexicalization of the forms representing the old standard. Lexicalization means that some lexemes assume new structures and forms with a visible, sometimes long delay. It also happens that for a longer or shorter time, and even until today, the old forms - owing to lexicalization - remain in the system of the Polish language as relics of long outdated standards. As a consequence, such variants disturb regularity, survive as exceptions or deviations from rules. Most often they are present in idioms and set phrases, functioning as petrified components of units of text. Another factor which might have influenced normalization internally in the 16th century was retardative impact of prepositional phrases. Still another factor having impact upon sixteenth-century normalization processes was regional variety of Polish, which was also important for the creation of the Polish literary language in that period. The last factor that must not be forgotten when considering normalization in the 16th century, is diversity stemming from stylistic differences between texts. What is meant by this, for instance, is characteristic distance of the language of poetry from colloquial Polish. It was manifested by the preference for the forms which had been already abandoned or even archaic at that time.

Taking into account all of the discussed reservations and assumptions, we are able to portray normalization of Polish in prints of the first half of the 16th century. This period was just the beginning of the era of the Polish printed book. Because of this reason, that time was decisive for the normalization processes of sixteenth-century literary Polish. In the first half of the 16th century, the development of printing houses, especially in Cracow, publishing more and more books in the native language, contributed to intensified activities 
aimed at limiting variety of language forms. This process leads to the elimination of variant forms in the language system but, of course, it occurs in language usage - in specific texts of personal language of the users of Polish ${ }^{8}$. The scope of systemic variation can be determined on the basis of the study of as many texts as possible (it would be best to study all texts, but, unfortunately, it is rather impossible for practical reasons) $)^{9}$. The observation and analysis of variation of language forms and limiting this variation allows us not only to define the degree of normalization of Polish in particular periods, but also to characterize the attitude to standards of sixteenth-century publishers of Polish books. So let's have a look at two collections of 16th-century texts with focus on normalization the Polish language used in them.

The first collection is made up by palaeotypes from years 1521-1522, among others the prints of Cracow:

- published in the house of Hieronim Wietor: Rozmowy, ktore miat krol Salomon madry z Marchottem grubym a sprosnym (1521), Ecclesiastes, Księgi Salomonowe (1522), Historyja (...) o szczęściu a o Swejwoli (1522), Księgi św. Augustyna biskupa Hippońskiego: O żywocie krzescijańskim (1522), of Balthasar Opec Żywot wszechmocnego Syna Bożego, Pana Jezu Krysta... (1522),

- published in the house of Florian Ungler edited by Jan Haller: Balthasar Opec Żywot Pana Jezu Krysta... prepared by Jan Sandecki-Malecki (1522).

The texts in the Polish language published until 1520 were mostly not self-standing prints - short supplements to foreign-language books (Wydra, Rzepka 1975: 263). The prints of Cracow from years 1521-1522 form the first chronologically compact collection of Polish palaeotypes ${ }^{10}$ known today. The fact that six titles were issued in two publishing houses competing with each other for market share in two successive years convinces us that these publications, and not earlier, sporadically published Polish books such as Raj duszny, exerted the greatest influence upon the pace of evolution of the general (literary) Polish language.

Variation of language forms and the normalization processes in those texts were explained by Tomasz Lisowski (Lisowski 1999).

The second collection of texts comprises the writings of Andrzej Glaber of Kobylin published in years 1535-1539 in the Cracow publishing house of Florian Ungler and his wife Helena where he was employed as an author, translator and editor-publisher:

- translation from Latin of the work by Maciej Miechowita Polskie wypisanie dwojej krainy świata, która po łacinie Sarmatia zowa (1535),

- Problemata Aristotelis. Gadki o składności człowieczych członków (1535),

- prepared for print Żołtarz Dawidów by Walenty Wróbel (1539).

\footnotetext{
${ }^{8}$ Mutual relationships between variants in the system and their functioning in personal language are presented by Władysława Książek-Bryłowa, see Książek-Bryłowa 1996.

${ }^{9}$ In the case of sixteenth-century Polish, the scope of systemic variation is best seen in Stownik polszczyzny XVI wieku ["Dictionary of 16th-Century Polish"], see SPXVI 1966-2012.

${ }^{10}$ This term is used in book science to designate the works of printing art which had been published until 1500 (in this case it is synonymous with the term incunabula). In Polish bibliography, however, as palaeotypes are considered the prints published until 1550, or even until the close of the 16th century (STSP: 160-161). Using the term palaeotypes, we mean the Polish books published in 1521 and 1522 in Cracow.
} 
Andrzej Glaber ${ }^{11}$ occupies a special place among 16th-century normalizers of the literary Polish. There were many reasons behind this. The two dialects that were fundamental for the shaping of the literary language: Great Polish and Little Polish were well-known by A. Glaber from his own language practice. Great Poland was the region he came from. He was born in Kobylin, spent his childhood there, and most probably, went to a parochial school at the Church of St. Stanislaus in his native town. In Little Poland he spent his adult life. However, the most important factor which predestined A. Glaber to consciously adopt the role of a normalizer of Polish was his thorough education which he mainly received during his studies and his later employment at the University of Cracow. A. Glaber received the highest academic degrees obtainable at university of that time: from the bachelor through the master to the professor of his Cracow alma mater. But what must be especially emphasized is very good language competence as well as language awareness represented by A. Glaber. Not without significance for his linguistic competence was good knowledge of foreign languages: Latin and German ${ }^{12}$, and also Greek, the fact which requires special emphasis as this skill was very rare at that time A. Glaber also possessed a wide theoretical knowledge about language, which resulted, among other things, from his authorship of a manual (or perhaps several manuals) of Latin grammar, of rhetoric and of dialectics of Latin grammar, of rhetoric and dialectics. So he perfectly knew not only the grammatical system of the Latin language, but also the rules of oratory skills. Additionally, his interest in literature, and thus the knowledge of numerous written works from that period, his writing talent and translation experience largely contributed to his language proficiency. Very close co-operation of A. Glaber with the publishing house of Florian Ungler and his wife Helena was also important in mastering language skills. Defining Andrzej Glaber as a prominent representative of the group of normalizers of the sixteenth-century literary Polish, it must be noted that he was respected in this role already by his contemporary scholarly circle at the University of Cracow, who commissioned him to prepare for print (mainly with regard to language), Żołtarz by Walenty Wróbel.

I discussed variant forms and normalization processes concerning phonetics and inflection in those texts in the paper about the language of Andrzej Glaber (Migdał 1999).

When analysing variation and normalization in the abovementioned texts, we realize previously discussed postulate of using the method of synchronic cross-sections. And by their juxtaposition and comparison, we can observe the processes occurring in the 16thcentury Polish.

It results from the analysis of variant forms in both groups of texts that the scope of variation of the Polish language used in these texts was very similar. There are just few differences connected with the incidence of variant forms. With regard to phonetics, for instance in palaeotypes, there are actually no variant forms connected with the occurrence of the groups -ow- and -ew-, because regular is the group -ow-, independently from a consonant preceding it. In Glaber's texts variation was present, although the forms with -ewhad been already relic variants, so we must speak in this respect about complete normalization. Here, it is worth to relate to the previously mentioned - as a factor influencing the

\footnotetext{
${ }^{11}$ Information about life and activity of Andrzej Glaber were mainly compiled from several biographic publications, see Barycz 1959-1960; Barycz 1971: 31; Czartoryski 1971; BLP; Świerzowski 1981; Wąsik 1916.

${ }^{12}$ Many scholars even claim that Andrzej Glaber's family was of German origin.
} 
process of normalization - lexicalization. In order for the normalization processes to correspond to the actual situation in the then Polish, we need to exclude from our calculations the forms królewicz, królewna, królewski, which in this very form, as lexicalized, survived until today ${ }^{13}$. Nevertheless, variant forms appeared in palaeotypes in the noun krolowa // krolewa (Lisowski 1999: 105-107). A. Glaber always uses this lexeme in the form krolowa.

In palaeotypes there are more oppositions creating a platform for variation with reference to forms connected with the influence of the Czech language and with reference to individual lexemes, which, in the texts of A. Glaber, did not appear in variant forms or did not occur at all. We find here such forms as: sierce // serce, piosnka // piesnka, of the type gańba // hańba, krolować // kralować, of the type szedt // szed, ćwi(e)rdzić // twi(e)rdzići, bojat sie // bat sie, kropia // kropla, teraz // tęraz (Lisowski 1999: 94-95, 99-100, 102-103, 104-105, 108-109, 112-113, 114, 118) 14 $^{14}$ and the forms: obrzazać // obrzezać, kamionować // kamienować, biada // bieda, wieczernik // wieczornik, gąbka // hubka, gwoźdź // goźdź (Lisowski 1999: 96-99, 100, 104, 115-116)15. One might say that this was so for "technical" reasons, because in the texts of Glaber there is no difference between bright vowels and narrowed vowels, the scope of variation in A. Glaber's publications is deprived of this category. But even in his texts there are variant forms that do not appear in palaeotypes. The following forms are included in this group stroża // straża, szczęście // szczeście, dziękować // dziekować, źwięk // dźwięk, poludnie // połdnie and the groups $k r-/ / c h r-$ in proper names and also -mgl-// -mdl- (Migdał 1999: 63-64, 72-73, 75-76, 79-80, 82).

Within inflection the convergence of variant oppositions is even bigger than at the level of phonetics. Actually, in palaeotypes we can find variant forms (not mentioned in A. Glaber's texts) only in two categories These are variants concerning present tense forms of the verb to be: jeś // jesteś, jeście // jesteście (in A. Glaber's texts these are exclusively the already transformed forms jesteś, jesteście) (Lisowski 1999: 243-245) and continuants of present tense active participles of simple conjugation: forms ending with -ąc, -ęcy, -ący, - $a$ (Glaber always uses the form with the suffix -ąc) (Lisowski 1999: 260-263).

It must be acknowledged that the standard of the text is made up by variants indicating the condition of complete and incomplete normalization. The studies conducted by Tomasz Lisowski show that the texts from Hieronim Wietor's printing house include 84 oppositions in which variation occurred and 52 of them represent the condition of complete and incomplete normalization, whereas, in the texts from Florian Ungler's publishing house there were as many as 54 such oppositions. Thus, it may be concluded that the Polish language of those texts was already normalized (in $62 \%-64 \%$ ). The standard of palaeotypes is, first of all, composed by traditional variants. For example, this is the form powiedac instead of powiadać (Lisowski 1999: 95-96), the ending - $e$ in genitive case of nouns in

13 Witold Mańczak (Mańczak 1964) and Marian Kucała (Kucała 1965) wrote about the reasons for preservation of the group - 'ev- in the mentioned words.

${ }^{14}$ In the texts of A. Glaber there are exclusively the forms: serce, piosnka, kropia, teraz and contracted forms of the verb bać sie. In anlaut of the mentioned lexemes hańba and twi(e)rdzić, the consonants $h-$ and $t$ - are always used. The verb krolowac appears only with a vernacular group TroT, and the forms of the type szedt occur only in unsimplified form.

15 There are no such lexemes in the publications of A. Glaber. 
feminine gender in singular into bright - $a$ (Lisowski 1999: 157-161), the ending -ech in locative case of hard-stem nouns in masculine gender in plural, excluding those with the stem starting with $-k,-g,-x$ (Lisowski 1999: 186-194), forms of simple conjugation of participle predicative expressions (Lisowski 1999: 210-219). However, the standard of those forms is not deprived of progressive elements. For instance, it is composed of such forms as: in phonetics - serce (not sierce) (Lisowski 1999: 94-95), wielki (not wieliki) (Lisowski 1999: 111-113), własny (not włosny) (Lisowski 1999: 100-101) or in inflection - the ending $-u$ in locative case of nouns in masculine gender in singular beginning with $k, g, x$ (Lisowski 1999: 148-151), the ending -owi in dative case of nouns in masculine gender in singular in factitive connections (Lisowski 1999: 140-148). Detailed analyses of particular oppositions reveal differences in the field of the normalization of texts coming from these two printing houses The normative attitudes adopted by the editor of Hieronim Wietor's prints and that of Jan Sandecki-Malecki were different. The former one promoted progressive forms, e.g., the ending -éj in genitive, dative and locative cases of adjectives and feminine gender pronouns (Lisowski 1999: 205-210), frequently regional - Little Polish, e.g., krolowa (instead of krolewa) (Lisowski 1999: 105-107). On the other hand, the proposals of J. Sandecki-Malecki are conservative and influenced by the Bohemian language, which can be seen in the preservation of the group ir (Lisowski 1999: 41-46) or the contracted forms of possessive pronouns (Lisowski 1999: 83-91).

Also Andrzej Glaber's texts should be acknowledged as texts representing a considerable level of normalization. This standard is made up of variants belonging to 106 detailed phonetic and inflectional categories, 67 of which are characterized by the condition of complete normalization and 39 of incomplete normalization. It is worth emphasizing that progressive variants prevail in this group, i.e., the variants that, in the course of the development of the Polish language, eventually prevailed. For example, among these variants can be found, in the field of phonetics, - the group -ow- occurring after soft consonants instead of the group -ev- (Migdał 1999: 39-42), missing nasal vowel in the lexeme smutek and cognate words (Migdał 1999: 64-65), the form wielki (not wieliki) (Migdał 1999: 81), the form kazdy (not kożdy) (Migdał 1999: 71-72), uncontracted forms of the possessive pronoun mój (Migdał 1999: 65-71), and the form łza without the velar nasal fricative consonant (not ztza) (Migdał 1999: 81-82). As far as inflection is concerned progressive variants constituting the standard of A. Glaber's texts include: the ending $-u$ in locative case of nouns in masculine and neutral gender in singular finished with dorsal consonants (Migdał 1999: 96-99, 119), the ending -ów in genitive case of nouns in masculine gender in plural (Migdał 1999: 106-108), the ending $-i / /-y$ in genitive case of soft-stem nouns in feminine gender in singular (Migdał 1999: 124-127), ), the ending - $e$ in accusative case of hardstem nouns in feminine gender in singular (Migdał 1999: 129-130), ), the ending -ach in locative case of nouns in neutral gender in singular (Migdał 1999: 123-124), the endings $-i m$ and $-y m$ in dative case of pronouns and adjectives in plural (Migdał 1999: 163-166), ), the ending - ej in genitive, dative and locative cases of adjectives in feminine gender in singular (Migdał 1999: 166-167), past tense forms with the auxiliary word transformed into an inflectional morpheme in the first and second person singular and plural and with the reduced auxiliary word in the third person singular and plural (Migdał 1999: 184-188), future tense constructions in singular built from the auxiliary word and participle $l$-owego (not with an infinitive) (Migdał 1999: 188-191), the ending -my in the first person plural 
in present and future tense, both simple and compound (Migdał 1999: 183-184), synthetic forms of imperative mode without a vowel $-i$ as the final sound (Migdał 1999: 191-194).

The detailed analysis of the variation of the Polish language used by Andrzej Glaber enables us to acknowledge him as a uniquely progressive normalizer of the Polish language. This is particularly observed in the forms which, although not included in the standard-forming variants and usually found among upstream or progressive variants, belong to such forms with which A. Glaber was often ahead of his own times. This group of variants embraces exclusively inflectional forms, for example, the ending -ami in instrumental case of masculine nouns in plural (Migdał 1999: 111-113), the ending-ach in instrumental case of masculine nouns in plural (Migdał 1999: 113-115) ${ }^{16}$, the form of the auxiliary word form bym in the first person singular in conditional mode (Migdał 1999: 194-198) or the form of the past active participle with the suffix -łszy following the consonantal stem. (Migdał 1999: 198-199).

While pointing out different aspects of variation and normalization of the Polish language from the 16th century, we mentioned stylistic factors impacting these processes. They were clearly distinct in A. Glaber's texts (Migdał 2000). The influence of the stylistic factor was especially manifested in these phonetic and inflectional categories in which occurred different proportions between particular variants used, on the one hand, in psalms and commentaries in Żołtarz and, on the other hand, those applied in Gadki and Wypisan$i e$. In this situation the first group includes predominantly regressive, conservatist variants whereas the texts from the second group include progressive forms. To the most characteristic differences of this type at the level of phonetics, belong, among others: domination of the group -ir- coming from the sonant proceeding labial and velar consonants in Żołtarz (Migdał 1999: 42-48), preservation of the diversification of a central nasal vowel in verb forms mainly in Żołtarz (in Gadki and Wypisanie these forms were exceptional (Migdał 1999: 52-54), lack of the softness anticipation in forms of nouns ociec and miestce and in their derivatives in Żołtarz (Migdał 1999: 60-63), dominance of uncontracted forms of possessive pronouns in Żołtarz while contracted forms dominated in the remaining texts (Migdał 1999: 65-71). As far as inflection is concerned, the following differences in forms can be pinpointed: the occurrence of lexicalized forms of the locative case Bodze, found only in Żołtarz (Migdał 1999: 96-99), lesser popularity of the endings -ach in locative case of masculine nouns in plural and the endings -ami in instrumental case of the neutral nouns in plural, with regard to connectivity with the entries in Żołtarz in contrast to other texts in which this ending appeared more frequently (Migdał 1999: 113-115, 121-123), bigger popularity of forms in nominative case in the nominal declination of adjectives and adjectival participles in singular and plural in Żołtarz comparing to a lesser frequency of these forms in Gadki and Wypisanie (13,33\%) (Migdał 1999: 145-151), the occurrence of forms of double number of pronouns solely in Żołtarz (Migdał 1999: 171-172) as well as the usage of compound past tense forms in the third person both singular and plural with an auxiliary word again only in Żołtarz (Migdał 1999: 184-188).

Such a diversification results from a distinct character of the texts. Not only does Żołtarz belong to religious literature but it is also a canonical text, a translation of the

${ }^{16}$ On the attitude of Andrzej Glaber towards forms participating in the process of demorphologization of gender in plural noun, see Migdał 2010. 
Biblical scripture. Thus, this genre required and requires the subordination to defined rules already established in the oldest translations of the Biblical style (Kossowska 1962; Kossowska 1968: 36-40; Skubalanka 1984: 34-35). One of the fundamental features of this style is a conscious archaization both at the level of grammar and vocabulary (Kossowska 1968: 40; Cybulski 1996: 90-91). Obviously, A. Glaber did not introduce genuine 16th-century archaisms, actually, these forms still functioned in the Polish language but were regressive variants. Thus, traditional elements, gradually disappearing from the living language, were used in this role. It was a specific type of archaization consisting in distancing the language used in the texts from the colloquial language of this period. ${ }^{17}$. This condition could be also achieved by the reduction of innovative elements. On the other hand, the selection of linguistic forms done by the authors of the texts of a utilitarian character, such as Gadki and Wypisanie, was completely different. The Polish language of such texts was characterized by a tendency to use variants originating from the spoken language i.e., those actually found in the contemporary usage. Consequently, conservative forms, strongly appealing to tradition, were avoided. Additionally, the latest variants, coming from colloquial Polish, relatively frequently appeared in these texts. The above presented differences result from the stylistic distinctiveness of A. Glaber's texts. It is worth mentioning that, oftentimes, the way of the variation forming, especially of these stylistically distinct phonetic and inflectional forms from the text of the commentaries to Żołtarz is similar to the situation in the remaining texts of A. Glaber. This similarity may stem from the less rigoristic Biblical style required in the commentaries. Although the commentaries are a part of the translation of the Biblical text thus constituting its integral part, their function differs substantially from the function of the psalms. They are an attempt at interpreting the canonical Biblical text and familiarizing a 16th-century reader with its contents. It can be said - for communicational reasons - their language less rigorously follows the rules of the Biblical style. Thus, to some degree, it resembles more the colloquial Polish language characteristic of such texts as Gadki and Wypisanie.

The analysis of variation in palaeotypes shows that the standard in these texts is "largely identical [...] and in this part has a traditional character although it is not deprived of progressive elements reflecting processes of the reconstruction of the Old-Polish system into the Middle-Polish system occurring in the general (literary) Polish" (Lisowski 1999: 284-285). However, dissimilarities in the normalization of these texts reveal a distinct character of a normative attitude of the editor of Hieronim Wietor's prints and those of Jan Sandecki-Malecki. The first one, with regard to differentiating features, promotes progressive forms, often regional - from Little Poland whereas J. Sandecki-Malecki's variants are conservative and influenced by the Bohemian language (Lisowski 1999: 277-290). While confronting these normative attitudes with Andrzej Glaber's stance it can be noticed that A. Glaber's progressive attitudes bring him closer to the editor of Wietor's prints. Although he published his texts in the same publishing house with which Jan Sandecki-Malecki was connected, he did not use his normalizing solutions. It is difficult to find here explicit references to the tradition of the normalization of Polish palaeotypes.

${ }^{17}$ Compare the remarks of Maria Renata Mayenowa about the poetic language of Jan Kochanowski and other writers of the 16th century - Mayenowa 1983. 
After comparison of the process of normalization of the Polish language, revealed in the analysis of palaeotypes from the period between 1521-1522 as well as Andrzej Glaber's works from the period between 1535-1539, it may be concluded that the first part of the 16th century was characterized rather by particular standards ${ }^{18}$. It is hard to talk here about a distinct continuity of the tradition of the normalization. However, it must be pointed out that in this period we can already see the developing but quite rapidly popularising progressive trend in the normalization of literary Polish. The group of these progressive normalizers definitely includes the anonymous editor of Żywot Pana Jezu Krysta printed in the publishing house of Hieronim Wietor, Jan from Koszyczek, Hieronim from Wieluń (Spiczyński) and Andrzej Glaber. In the later period also Jan Seklucjan and Stanisław Murzynowski joined this group, the polemicists who broke the old linguistic traditions of Jan Sandecki-Malecki. Eventually, the progressive trend in the normalization of the Polish language triumphed. Nowadays, from the perspective of time, on the basis of the findings of numerous historical-linguistic analyses, the victory of this progressive option is quite apparent.

\section{Bibliography}

Bajerowa I., 1964, Ksztaltowanie się systemu polskiego języka literackiego w XVIII wieku, Wrocław. Bajerowa I., 1969, Strukturalna interpretacja historii języka, „Język Polski” XLIX, s. 81-103.

Bajerowa I., 1980a, Wpływ techniki na ewolucję języka polskiego, Kraków.

Bajerowa I., 1980b, Zmiany fleksji zaimków w XIX-wiecznej polszczyźnie ogólnej (normalizacja i przekształcenia normy). „Język Polski” LX, s. 105-114.

Bajerowa I., 1983, Znaczenie wariancji w ewolucji języka ogólnego, „Biuletyn Polskiego Towarzystwa Językoznawczego" XL, (wyd. 1988), s. 19-23.

Bajerowa I., 1984, Frekwencja form i badanie procesów historycznojęzykowych, „Biuletyn Polskiego Towarzystwa Językoznawczego" XLI, s. 69-81.

Barycz H., 1959-1960, Glaber Andrzej, w: Polski słownik biograficzny, t. 8, Wrocław, s. 28-30.

Barycz H., 1971, Znaczenie Uniwersytetu Krakowskiego w poczatkach rozwoju erazmianizmu w Polsce, w: Erasmiana Cracoviensia. W 500-lecie urodzin Erazma z Rotterdamu (1469-1536), „Zeszyty Naukowe Uniwersytetu Jagiellońskiego” CCL, „Prace Historyczne” 33, s. 23-38.

BLP - Bibliografia literatury polskiej „,Nowy Korbut”. Piśmiennictwo staropolskie, t. 2, red. R. Pollak, Warszawa 1963, hasło Glaber, s. 191.

Borecki M., 1974, Kształtowanie się normy językowej w drukach polskich XVI wieku (na przykładzie oboczności typu pirwszy // pierwszy), Wrocław.

Cybulski M., 1996, Staropolskie przekłady psałterza, „Rozprawy Komisji Językowej Łódzkiego Towarzystwa Naukowego" XLI.

Czartoryski P., 1971, Glaber Andrzej, w: Filozofia w Polsce. Słownik pisarzy, Wrocław, s. 94-95.

EJO - Encyklopedia językoznawstwa ogólnego, red. K. Polański, Wrocław 1993, hasło: Norma językowa, s. 362.

Kossowska M., 1962, Z dziejów polskiego stylu psałterzowego, „Język Polski” XCII, s. 135-148, 194-212.

18 In order to obtain a complete picture of the Polish language in the first half of the 16th century, it is worth to compare the language of prints with the language of other texts from that period, e.g., letters. Marek Osiewicz, in his papers, studied Polish used in those letters, see Osiewicz 2006a; Osiewicz 2006b; Osiewicz 2007a; Osiewicz 2007b; Osiewicz 2008; Osiewicz 2009; Osiewicz 2010; Osiewicz 2012. 
Kossowska M., 1968, Biblia w języku polskim, t. 1, Poznań.

Książek-Bryłowa W., 1986, Uwarunkowania społeczne normy językowej w XVI wieku, „Rozprawy Komisji Językowej Łódzkiego Towarzystwa Naukowego" XXXII, s. 139-146.

Książek-Bryłowa W., 1987, Stałe i zmienne czynniki w rozwoju polskiej fleksji (na przykładzie rzeczowników żeńskich spółgłoskowych typu kieszeń), „Poradnik Językowy”, s. 191-197.

Książek-Bryłowa W., 1992, Warianty fleksyjne w historii języka polskiego, w: T. Skubalanka, W. Książek-Bryłowa, Wariantywność polskiej fleksji, Wrocław, s. 117-190.

Książek-Bryłowa W., 1994, Wariantywność fleksji w historii i gwarach języka polskiego, Lublin.

Książek-Bryłowa W., 1996, Warianty $w$ systemie a warianty $w$ idiolekcie, „Prace Językoznawcze. Studia Historycznojęzykowe" 24, Katowice, s. 18-25.

Kucała M., 1965, Jeszcze o formach królewna, królewicz, królewski, „Sprawozdania z Posiedzeń Komisji Naukowych Polskiej Akademii Nauk. Oddział w Krakowie”, s. 33-35.

Kurkowska H., 1986, Teoretyczne zagadnienia kultury języka, w: D. Buttler, H. Kurkowska, H. Satkiewicz, Kultura języka polskiego. Zagadnienia poprawności gramatycznej, Warszawa, s.

Lewaszkiewicz T., 1994, O potrzebie nowego spojrzenia na geneze polskiego języka literackiego (z uwzględnieniem tta ogólnoeuropejskiego), w: Studia historycznojęzykowe I, red. M. Kucała, Z. Krążyńska, Kraków, s. 213-220.

Lisowski T., 1999, Polszczyzna początku XVI wieku. Problemy wariantywności i normalizacji fonetyki i fleksji, Poznań.

Mayenowa M.R., 1983, O języku poezji Jana Kochanowskiego, Kraków.

Mańczak W., 1964, O formach królewna, królewicz, królewski, „Sprawozdania z Posiedzeń Komisji Naukowych Polskiej Akademii Nauk. Oddział w Krakowie", s. 366-368.

Migdał J., 1999, O języku Andrzeja Glabera z Kobylina. Studium polszczyzny wczesnorenesansowej, Poznań.

Migdał J., 2000, Fonetyczne i fleksyjne formy jako wyznaczniki stylu biblijnego $w$ drukowanej wersji Żołtarza Dawidowego Walentego Wróbla, w: Inspiracje chrześcijańskie w kulturze Europy, Łódź, s. 219-231.

Migdał J., 2010, Progresywny czy tradycyjny - o postawie normatywnej Andrzeja Glabera z Kobylina $w$ zakresie demorfologizacji rodzaju rzeczownika $w$ formach celownika, narzędnika i miejscownika liczby mnogiej, „Poznańskie Studia Polonistyczne. Seria Językoznawcza” XVI, s. 173-182.

Osiewicz M., 2006a, Samogłoski nosowe w listach polskich z lat 1525-1550, „Slavia Occidentalis” 63, s. $85-97$.

Osiewicz M., 2006b, Wariantywność form fleksyjnych rzeczowników w listach polskich z lat 1525-1550 (rzeczowniki rodzaju męskiego), „Poznańskie Studia Polonistyczne. Seria Językoznawcza” XIII, s. $101-128$.

Osiewicz M., 2007a, Wariantywność form fleksyjnych rzeczowników w listach polskich z lat 1525-1550 (rzeczowniki rodzaju żeńskiego i rzeczowniki o odmianie mieszanej), „Poznańskie Studia Polonistyczne. Seria Językoznawcza" XIV, s. 163-195.

Osiewicz M., 2007b, Wariantywność leksemów w zakresie nieseryjnych zmian fonetycznych $w$ listach polskich z pierwszej połowy XVI wieku, Poznań.

Osiewicz M., 2008, Oddziaływanie spółgłosek nosowych na poprzedzajace je samogłoski nosowe w listach polskich z lat 1525-1550, „Slavia Occidentalis” 65, s. 77-94.

Osiewicz M., 2009, Wariantywność form fleksyjnych rzeczowników w listach polskich z lat 1525-1550 (rzeczowniki rodzaju nijakiego; rzeczowniki typu podskarbi, podczaszy; pluralia tantum; pluralne nazwy geograficzne; formy liczby podwójnej), „Poznańskie Studia Polonistyczne. Seria Językoznawcza" XV, s. 223-159.

Osiewicz M., 2010, Wariantywność w zakresie realizacji grup spółgłoskowych $w$ listach polskich z pierwszej połowy XVI wieku (kontynuanty połączeń *sí, *zŕ, *žŕ, *-(s)tbc-, *-(z)dьc- oraz grupy (-)vš-, (-)xv-, -dl-), „Poznańskie Studia Polonistyczne. Seria Językoznawcza” XVI, s. 183-199. 
Osiewicz M., 2012, Oddziaływanie spółgłosek płynnych na poprzedzające je samogłoski wąskie nietylne (na materiale listów polskich z I połowy XVI wieku), „Slavia Occidentalis” 69, s. 185-198.

Rospond S., 1956, Problem genezy polskiego języka literackiego. Uwagi polemiczne do artykułów T. Milewskiego i W. Taszyckiego, w: Pochodzenie polskiego języka literackiego. Studia staropolskie III, red. K. Budzyk, Wrocław, s. 117-177.

Rzepka W.R., 1985, Demorfologizacja rodzaju w liczbie mnogiej rzeczowników w polszczyźnie XVI-XVII wieku, Poznań.

Skubalanka T., 1984, Historyczna stylistyka języka polskiego, Wrocław.

Skubalanka T., 1992, Warianty fleksyjne we współczesnej polszczyźnie, w: T. Skubalanka, W. KsiążekBryłowa, Wariantywność polskiej fleksji, Wrocław, s. 7-116.

SPXVI - Stownik polszczyzny XVI wieku, t. I-XXXVI, red. M.R. Mayenowa, F. Pepłowski, K. Mrowcewicz, Wrocław-Warszawa-Kraków - Warszawa 2012.

STSP - Słownik terminologiczny sztuk pięknych. Wydanie nowe, red. K. Kubalska-Sulkiewicz, M. Bielska-Łach, A. Manteuffel-Szarota, Warszawa 1996, hasło: Inkunabut, s. 160-161.

Świerzowski K., 1981, Żywot i sprawy Andrzeja Glabera z Kobylina. (Nowe źródła i materiały), w: Silva rerum, Kraków, s. 40-56.

Taszycki W., Milewski T., 1956, Nowe prace o pochodzeniu polskiego języka literackiego, w: Pochodzenie polskiego języka literackiego. Studia staropolskie III, red. K. Budzyk, Wrocław, s. $60-81$.

Urbańczyk S., 1977, Hierarchia kryteriów poprawności językowej we współczesnym języku polskim, w: Wariancja normy we współczesnych stowiańskich językach literackich, red. S. Urbańczyk, Wrocław, s. 75-83.

Urbańczyk S., 1979, Głos w dyskusji o pochodzeniu polskiego języka literackiego, w: S. Urbańczyk, Prace z dziejów języka polskiego, Wrocław, s. 188-205.

Walczak B., Komu zawdzięczamy polski język literacki?, w: Język a chrześcijaństwo, red. I. Bajerowa, M. Karpluk, Z. Leszczyński, Lublin 1993, s. 23-42.

Wąsik W., 1916, Andrzej Glaber z Kobylina, problematysta polski, „Przegląd Filozoficzny” XIX, s. $71-140$.

Wydra W., Rzepka W.R., 1975, Niesamoistne drukowane teksty polskie sprzed roku 1521 i ich znaczenie dla historii drukarstwa i języka polskiego, w: Dawna ksiązka i kultura. Materiały międzynarodowej sesji naukowej z okazji pięćsetlecia sztuki drukarskiej w Polsce, red. S. Grzeszczuk, A. Kawecka-Gryczowa, Wrocław, s. 263-288.

\title{
JOLANTA MIGDAE
}

\section{Variation and Normalization of the Polish Language in the Old Prints from the First Half of the 16th Century}

\begin{abstract}
Summary
The article presents normalization of the Polish literary language in prints from the first half of the 16th century. It was a breakthrough period for the normalization process in which the activities aimed at limiting the variation of language forms were intensified. The linguistic analysis presented here focuses on two groups of sixteen-century texts: Polish palaeotypes, that is the prints from Cracow from the years 1521-1522 as well as on the writings of Andrzej Glaber of Kobylin published in the years 1535-1539 in the Cracow publishing house of Florian Ungler and his wife Helena where he performed various functions: of an author, translator and editorpublisher.
\end{abstract}


The observation and study of variance of language forms and its limitation enables us not only to determine the degree of normalization of the Polish language in particular periods, but also to characterize the attitude to standards of sixteen-century publishers of Polish books.

On the basis of the comparison of normalization of Polish in palaeotypes from the years 1521-1522 and in the works of Andrzej Glaber from the years 1535-1539 we can conclude that the first half of the 16th century was characterized by particular standards. It is difficult to notice an apparent continuity of the normalization tradition. Nevertheless, we can discern in this period a developing progressive trend in the normalization of the Polish literary language which quickly became widespread. The group of progressive normalizers definitely includes: the anonymous editor of Żywot Pana Jezu Krysta, printed in the publishing house of Hieronim Wietor, Jan from Koszyczki, Hieronim from Wieluń (Spiczyński) and Andrzej Glaber. In the later period also Jan Seklucjan and Stanisław Murzynowski joined this group, the polemicists who broke the old linguistic traditions of Jan Sandecki-Malecki. Nowadays, on the basis of the findings of numerous historical-linguistic analyses, the victory of this progressive option is quite apparent..

Keywords: sixteenth-century Polish language, normalization, variance of language forms, the role of sixteenth-century printers 